\title{
Efektifitas Penerapan Prinsip Syariah dalam Penyelesaian Sengketa Ekonomi Syariah di Badan Arbitrase Syariah Nasional (BASYARNAS)
}

\author{
Zaidah Nur Rosidah', Layyin Mahfiana ${ }^{2}$ \\ Institut Agama Islam Negeri Surakarta \\ zaidahnurr@yahoo.com ${ }^{1}$, layin.oke@gmail.com²
}

\begin{abstract}
This study aims to determine the application of sharia principles in sharia economic dispute resolution in the National Sharia Arbitration Agency (Basyarnas). This study uses a method of socio legal study, how sharia principles are applied in resolving sharia economic disputes so that they can provide justice for both parties. Secondary data collection is carried out through a literature study of primary legal materials and secondary legal material. Some data was requested for confirmation from the National Sharia Arbitration Agency (Basyarnas) in the Yogyakarta region. To obtain answers to the research problems, 3 activities were carried out simultaneously, namely data reduction, data presentation, conclusion drawing / syllogistic verification of deduction. The results of the research and discussion obtained several conclusions, namely first, Islamic principles have not been maximally implemented by Basyarnas, this can be seen from the basis of the consideration of Basyarnas law in its decision. Basyarnas should also correct in terms of the contract, whether it is in accordance with sharia principles or not so that the arising of the dispute is not solely due to the default of the customer but can also be caused by incompatibility with sharia principles. Second, according to Antony Allot's theory of legal effectiveness, the application of sharia principles in sharia economic dispute resolution has not been carried out in accordance with sharia principles, this is due to the lack of clarity in the case in Basyarnas' decision.
\end{abstract}

Keywords: Effectivity, Sharia Principles, Sharia Economic Disputes, Basyarnas.

\begin{abstract}
Abstrak
Penelitian ini bertujuan untuk mengetahui penerapan prinsip-prinsip syariah dalam penyelesaian sengketa ekonomi syariah di Badan Arbitrase Syariah Nasional (Basyarnas). Penelitian ini menggunakan metode pendekatan socio legal study, bagaimana prinsip-prinsip syariah diterapkan dalam menyelesaikan sengketa ekonomi syariah sehingga dapat memberikan keadilan bagi kedua belah pihak. Pengumpulan data sekunder dilakukan melalui studi pustaka bahan hukum primer dan bahan hukum sekunder. Beberapa data dimintakan konfirmasi kepada Badan Arbitrase Syariah Nasional (Basyarnas) wilayah Yogyakarta. Untuk memperoleh jawaban atas permasalahan penelitian dilakukan 3 alur kegiatan yang terjadi secara bersamaan yaitu reduksi data, penyajian data, penarikan kesimpulan/verifikasi silogisme deduksi. Hasil penelitian dan pembahasan diperoleh beberapa simpulan yaitu pertama, prinsipprinsip syariah belum maksimal diterapkan oleh Basyarnas, hal ini dapat dilihat dari dasar pertimbangan hukum Basyarnas dalam putusannya. Seharusnya Basyarnas juga mengoreksi dari segi akad, apakah sudah sesuai dengan prinsip syariah atau tidak sehingga timbulnya sengketa bukan semata-mata
\end{abstract}


disebabkan oleh wanprestasinya nasabah akan tetapi dapat juga disebabkan karena tidak sesuainya akad dengan prinsip-prinsip syariah. Kedua, menurut teori efektivitas hukum dari Antony Allot bahwa penerapan prinsipprinsip syariah dalam penyelesaian sengketa ekonomi syariah belum berjalan sesuai dengan prinsip syariah, hal ini disebabkan karena tidak jelasnya duduk perkara dalam putusan Basyarnas.

Kata Kunci: efektivitas, Prinsip-Prinsip Syariah, Sengketa Ekonomi Syariah, Basyarnas.

\section{PENDAHULUAN}

Perkembangan ekonomi syariah di Indonesia saat ini cukup menggembirakan. Sejak munculnya bank syariah pertama yaitu bank Muamalat, maka bermunculan bank-bank lain yang menerapkan prinsip syariah. Bahkan sampai sekarang hampir semua bank konvensional telah membuka unit usaha syariah atau mendirikan bank sendiri yang menggunakan prinsip syariah. Tidak saja perbankan yang tumbuh pesat, akan tetapi berbagai lembaga keuangan syariah juga sudah bermunculan. Bahkan beberapa lembaga yang semula tidak menggunakan prinsip syariah sekarang banyak yang berganti nama atau bahkan memberikan label syariah di belakangnya. Munculnya hotel syariah, pariwisata syariah selain yang sudah berkembang sebelumnya perbankan syariah, asuransi syariah dan pegadaian syariah.

Berbagai macam lembaga yang menggunakan label syariah tersebut di dalam pelaksanaan kegiatan harus menggunakan prinsipprinsip syariah. Dalam operasionalnya perbankan syariah merupakan bagian dari sistem ekonomi Islam sehingga dituntut untuk tidak saja menghasilkan keuntungan melalui setiap transaksi komersial saja, tetapi juga untuk mengimplementasikan nilai-nilai syariah yang sesuai dengan Al-Qur'an dan Al-Hadits (Abdul Shomad, 2010: 83).

Sengketa ekonomi syariah merupakan suatu perselisihan atau pertentangan antara dua pihak atau lebih pelaku ekonomi yang kegiatan usahanya dilaksanakan menurut prinsip-prinsip syariah dan asas-asas hukum ekonomi syariah yang disebabkan karena perbedaan pendapat atau perbedaan penafsiran terhadap suatu kepentingan atau hak milik yang dapat menimbulkan akibat hukum bagi keduanya dan dapat diberikan sanksi hukum atau menimbulkan kerugian terhadap satu di antara keduanya.

Timbulnya sengketa antara para pihak pada dasarnya sangat tidak dikehendaki oleh pelaku ekonomi, namun demikian dalam menjalankan usaha risiko timbulnya sengketa tetap dapat terjadi. Di dalam masyarakat bila terjadi sengketa yang diselesaikan melalui berbagai cara. Masing-masing pendekatan menggunakan paradigma yang berbeda sesuai dengan nilai, keinginan, tujuan, budaya yang diyakini 
pihak yang sedang bersengketa. Pendekatan pertama, yaitu penyelesaian sengketa melalui pengadilan (litigasi). Pendekatan ini merupakan suatu pendekatan untuk mendapatkan keadilan melalui sistem perlawanan dan menggunakan paksaan dalam mengelola sengketa serta menghasilkan suatu keputusan win-lose solutioan bagi pihak-pihak yang bersengketa. Sementara itu, pendekatan kedua, paradigma penyelesaian sengketa melalui jalur di luar pengadilan (non litigasi). Paradigma ini dalam mencapai keadilan lebih mengutamakan pendekatan perdamaian dan berusaha mempertemukan kepentingan pihak-pihak yang bersengketa serta bertujuan untk mendapatkan hasil peneyelesaian sengketa kearah win-win solution, tidak ada pihak yang menang dan pihak lain yang kalah (Adi Sulistiyono, 2006: 2-5).

Penggunaan arbitrase dengan berbagai keistimewaannya untuk menyelesaikan sengketa ekonomi syariah, di bidang keperdataan merupakan pilihan yang tepat. Menurut Achmad Djauhar dalam Muhammad Arifin, arbitrase syariah menjadi sarana yang perlu dimanfaatkan oleh umat Islam Indonesia dalam mengikuti perkembangan dan aktivitas perbankan syariah. Dikatakan oleh Tahir Azhary kehadiran arbitrase Islam di Indonesia merupakan suatu conditio sine qua non (Muhammad Arifin, 2016a: 7). Arbitrase syariah pada perkembangan saat ini menjadi satu forum penyelesaian sengketa perbankan syariah. Perkembangan industri perbankan syariah menghendaki penguatan arbitrase syariah sebagai pilar penyangga, dalam menghadapi dan menyelesaikan setiap kemungkinan terjadi perselisihan dalam aktivitas perbakan syariah. Penguatan arbitrase syariah akan memperkuat sistem hukum perbankan syariah dalam konteks penyelesaian sengketa yang terjadi di lingkungan perbankan syariah (Muhammad Arifin, 2016b:7).

Penelitian yang dilakukan oleh Rika Defta Zoya tahun 2014 dengan judul Penyelesaian Sengketa Perbankan Syariah di Indonesia diperoleh kesimpulan, bahwa penyelesaian sengketa perbankan syariah di Indonesia melalui jalur non litigasi dapat dilakukan melalui musyawarah, mediasi perbankan, arbitrase syariah, dan pengadilan dalam lingkungan Peradilan Umum. Basyarnas adalah forum paling strategis untuk menyelesaikan sengketa perbankan syariah. Karena Basyarnas dapat menyelesaikan sengketa dengan lebih cepat, sederhana, dan biaya ringan. Selain itu penyelesaian melalui arbitrase syariah juga dapat lebih menjaga rahasia masing-masing pihak. Meskipun demikian, kurangnya sosialisasi Basyarnas kepada masyarakat, dan jaringan kantor Basyarnas yang masih terbatas di ibu kota, menjadikan Basyarnas kurang dikenal sebagai lembaga arbiter dalam penyelesaian sengketa perbankan syariah (Rika Defta Zona, 2014). 
Penelitian lain yang telah dilakukan oleh Nurhasanah dan Hotnidah Nasution dengan Judul Kecenderungan masyarakat memilih lembaga penyelesaian sengketa ekonomi syariah, diperoleh kesimpulan bahwa lembaga keuangan syariah sangat beragam, untuk memilih cara dan memilih lembaga penyelesaian sengekta ekonomi syariah ada yang memilih pengadilan agama, Basyarnas, lembaga ADR lainnya bahkan pengadilan negeri. Beragamnya pilihan responden untuk memilih lembaga penyelesaian sengketa dipengaruhi oleh 5 faktor yaitu regulasi, asas kebebasan berkontrak, sumber daya manusia, kelembagaan dan efisiensi waktu serta biaya berperkara (Nurhasanah, dkk, 2016: 280).

Demikian juga peneltian yang dilakukan oleh Fikri La Hafi dan Budiman, dengan judul Penerapan Asas Lex Specialis Derogat Legi Generalis dan Penyelesaian Sengketa Ekonomi dalam Undang-Undang Perbankan Syariah di Indonesia menyatakan bahwa Undang-Undang Republik Indonesia Nomor 23 Tahun 2004 tentang Perubahan atas Undang-Undang Republik Indonesia Nomor 10 Tahun 1998 tentang Bank Indonesia, yang berlaku umum. Sedangkan Undang-Undang Republik Indonesia Nomor 21 Tahun 2008 tentang Perbankan Syariah, berlaku khusus. Penerapan asas lex specialis derogat legi generali menegaskan bahwa Undang-Undang Republik Indonesia Nomor 21 Tahun 2008 memiliki kedudukan lebih kuat dibandingkan UndangUndang Republik Indonesia Nomor 23 Tahun 2004 yang berlaku umum. Keberlakuan Undang-Undang Republik Indonesia Nomor 21

Tahun 2008 mengokohkan eksistensi perbankan syariah untuk leluasa menjalankan aktivitas dan produk-produknya. Di samping itu, apabila merujuk kepada Undang-Undang Republik Indonesia Nomor 30 Tahun 1999, maka penyelesaian sengketa perbankan syariah dapat ditempuh melalui dua cara yaitu, pengadilan negeri dan badan arbitrase. Namun setelah berlakunya Undang-Undang Republik Indonesia Nomor 21 Tahun 2008 Pasal 55, dengan jelas disebutkan bahwa pengadilan yang berwenang melaksanakan putusan Badan Arbitrase Syariah Nasional (Basyarnas) dan menyelesaikan sengketa perbankan syariah adalah pengadilan agama (Fikri La Hafi, Budiman, 2017: 149).

Putusan Basyarnas mempunyai kekuatan hukum yang mengikat. Salinan putusan basyarnas kemudian dikirimkan ke pangadilan agama. Pengiriman putusan tersebut agar dapat dilaksanakan atau dieksekusi. Sehingga pihak-pihak yang berselisih dapat menjalankan isi putusan dengan sukarela. Apabila perkara tersebut sudah diputus oleh Basyarnas, maka perkara tersebut tidak dapat diajukan kembali ke pengadilan.

Berbeda dengan putusan pengadilan, keputusan arbitrase tidak dapat dibanding. Apabila perkara diselesaikan di pengadilan agama, dan ada pihak yang tidak puas dengan putusan tersebut, maka ada upaya hukum yang dapat dilakukan yaitu banding, kasasi, bahkan peninjauan 
kembali. Bagi perusahaan besar jauh lebih efisien bila menggunakan Basyarnas. Putusan Basyarnas bersifat rahasia, singkat dan sederhana. Berbeda dengan perkara di pengadilan yang dapat disaksikan oleh publik. Bahkan putusan pengadilan harus diumumkan untuk publik. Namun demikian penyelesaian sengketa ekonomi syariah di Basyarnas juga harus mengedepankan aspek keadilan bagi para pihak. Dan Basyarnas juga harus berpedoman pada prinsip syariah di dalam menyelesaian sengketa. Penerapan prinsip syariah dalam penyelesaian sengketa antar para pihak inilah yang menarik minat peneliti untuk melakukan penelitian di badan arbitrase syariah nasional. Bagaimana penerapan prinsip-prinsip syariah dalam menyelesaikan sengketa sehingga keadilan dapat diwujudkan diantara para pihak. Para pihak sama-sama memperoleh kemenangan atas sengketa tersebut.

\section{KAJIAN LITERATUR}

\section{Teori efektivitas Hukum menurut Anthony Allot}

Untuk dapat mewujudkan tujuan hukum, diperlukan keadaan-keadaan atau upaya-upaya tertentu sehingga keberadaan hukum mempunyai pengaruh terhadap tindakan dan perbuatan manusia. Keadaan atau upaya yang dapat dilakukan agar keberadaan hukum ditaati oleh menusia adalah dengan melakukan sosialisasi dan komunikasi yang baik sehingga tanggapan seseorang terhadap aturan itu menjadi posistif. Perwujudan dari sikap positif manusia adalah dengan mentaati aturan yang telah diundangkan tersebut. Kecenderungan sikap seseorang terhadap aturan itulah yang nantinya mempunyai pengaruh terhadap pelaksanaan hukum. Ketaatan seseorang terhadap hukum dipengaruhi pada apakah sikap dan tanggapan mereka terhadap hukum positif atau negatif.

Efektif mengandung pengertian efek keberhasilan dari hukum. Untuk mengukur suatu aturan hukum itu efektif atau tidak dengan melihat berbagai macam faktor yang mempengaruhinya. Hal yang perlu diperhatikan apakah hukum efektif atau tidak adalah dari segi ketaatan seseorang terhadap aturan itu. Jika hampir sebagian besar manusia yang menjadi sasaran target aturan itu mentaati, maka dapat dikatakan hukum menjadi efektif. Demikian sebaliknya apabila target sasaran hukum itu tidak banyak yang patuh maka hukum dikatakan tidak efektif. Tingkat ketaatan seseorang kepada hukum tidak semata-mata dipengaruhi oleh hukum itu sendiri, ada faktor di luar hukum yang juga mempunyai pengaruh berlakunya hukum yaitu penegakan hukum. Sebagaimana yang dikemukakan oleh Sooerjono Soekanto bahwa kepatuhan seseorang terhadap hukum merupakan pertanda bahwa tujuan hukum dapat tercapai. Tingginya tingkat kepatuhan itulah yang menjadi ukuran hukum diakatan efektif atau tidak. 
Menurut Anthony Allot, hukum dikatakan efektif jika tujuan keberadaan hukum dan penerapannya dapat mencegah tindakantindakan atau perbuatan-perbuatan manusia yang tidak diinginkan dapat mencapai kedamian hidup. Hukum dikatakan efektif jika tujuan yang dikehendaki oleh adanya norma atau aturan tersebut dapat terwujud, apabila tujuan yang dikehendaki tersebut belum terwujud atau terjadi kegagalan untuk mewujudkannya, maka hukum dapat menyelesaikannya. Fokus dari teori efektivitas hukum Anthony Allot ini ada pada perwujudan tujuan hukum. Kerena secara umum tujuan pembentukan hukum adalah bagaimana kehidupan sosial masyarakat yang tertib, damai dapat terwujud.

\section{Sengketa Ekonomi Syariah}

Di dalam kamus Besar Bahasa Indonesia, pengertian sengketa adalah pertentangan, perselisihan, atau percekcokan yang terjadi antara pihak yang satu dengan pihak lainnya yang berkaitan dengan hak yang bernilai, baik berupa uang atau benda. Achmad Ali dalam Amran Suadi, sengketa atau konflik merupakan setiap situasi pertentangan kepentingan antara dua orang atau lebih di mana dua atau lebih pihak yang memperjuangkan tujuan-tujuan tertentu dari masing-masing pihak, saling memberikan tekanan dan satu sama lain tetapi gagal mencapai satu pendapat dan masing-masing pihak saling berusaha untuk memperjuangkan secara sadar tujuan-tujuan pokok mereka yang kehendaki (Amran Suadi, 2018a: 30).

Pada umumnya, sengketa yang mucul dikarenakan ada wanprestasi atau ingkar janji oleh pihak-pihak atau salah satu pihak tidak melakukan apa yang diperjanjikan atau disepakati untuk dilakukan, atau pihak yang satu melaksanakan apa yang disepakati tetapi tidak tunai, atau pihak yang satu melaksanakan apa yang diperjanjikan tetapi keliru dan atau salah satu pihak melaksanakan prestasi atau apa yang diperjanjikan tetapi tidak tepat waktu, sehingga apa yang dilakukan oleh salah satu pihak inilah yang memicu timbulnya sengketa.

Diantara faktor penyebab yang lazim terjadi dalam sengketa ekonomi syariah adalah : (Amran Suadi, 2018b: 33).

a. Akad yang dibuat oleh para pihak yang tidak transparan atau hanya ditentukan oleh salah satu pihak saja terutama pihak yang berada pada posisi yang kuat, sehingga pihak yang lain tidak memahami isi akad dengan baik

b. Isi akad yang tidak mudah untuk dilaksanakan karena :

1) Salah satu pihak yang kurang hati-hati dalam melakukan perundingan,

2) Salah satu pihak tidak mempunyai keahlian di dalam negosiasi kesepakatan isi akad, 
3) Salah satu pihak tidak mempunyai keahlian di dalam mencermati risiko yang mungkin akan terjadi dari akad tersebut atau

4) Salah satu pihak tidak jujur dalam melaksanakan akad.

Dari segi akad atau perjajian yang dibuat oleh para pihak, ada beberapa bentuk akad yang berpotensi sengketa di kemudian hari, diantaranya adalah: (Amran Suadi, 2018c: 33-34).

1) Salah satu pihak menemukan fakta bahwa syarat-syaratnya suatu akad, baik syarat subjektif maupun objektif yang ternyata tidak terpenuhi sehingga menuntut pembatalan akad;

2) Akad diputus oleh satu pihak tanpa persetujuan pihak lain dan perbedaan menafsiran isi akad oleh para pihak sehingga menimbulkan sengketa hukum;

3) Karena salah satu pihak tidak memenuhi prestasi sebagaimana yang telah diperjanjikan;

4) Terjadinya perbuatan melawan hukum

5) Adanya risiko yang tidak terduga pada saat pembuatan akad.

\section{Tinjauan tentang Arbitrase}

Arbitrasi berasal dari bahasa Latin "arbitrare" yang berarti "kekuasaan untuk menyelesaikan sesuatu perkara menurut kebijaksanaan". Pengertian ini walaupun dengan terminologi yang sama tetapi dikemukakan berbeda-beda oleh para sarjana saat ini. Menurut Subekti menyatakan bahwa arbitrase adalah penyelesaian atau pemutusan sengketa oleh hakim atau para hakim yang mereka pilih, dan para pihak mentaati apa yang menjadi keputusan dari hakim yang dipilih tersebut (Subekti, 1992: 1).

Penggunaan arbitrase dengan berbagai keistimewaannya untuk menyelesaikan sengketa perbankan syariah, di bidang keperdataan (muamalah) merupakan pilihan yang tepat. Arbitrase syariah sebagai salah satu lembaga penyelesaian sengketa di luar pengadilan dapat dimanfaatkan oleh umat Islam yang menghadapi atau mengalami perselisihan dalam bidang ekonomi syariah. Menurut Tahir Azhary dalam Muhammad Arifin, keberadaan arbitrase syariah sudah menjadi suatu keniscayaan. Arbitrase syariah pada perkembangan saat ini menjadi salah satu forum penyelesaian sengketa perbankan syariah. Perkembangan industri perbankan syariah menghendaki penguatan arbitrase syariah sebagai pilar penyangga, dalam menghadapi dan menyelesaikan setiap kemungkinan terjadi perselisihan dalam aktivitas perbankan syariah. Penguatan arbitrase syariah akan memperkuat sistem hukum perbankan syariah dalam konteks penyelesaian sengketa yang terjadi di lingkungan bank syariah (Muhammad Arifin, 2016c : 7).

Arbitrase syariah bisa digunakan sebagai salah satu pilihan penyelesaian sengketa antara para pihak di luar pengadilan. Terminologi 
arbitrase yang dikenal pada masa modern saat ini sebagai forum penyelesaian sengketa di luar pengadilan (out court system), dalam perspektif hukum Islam sepadan dengan tahkim. Menurut Wahbah AzZuhaili dalam Muhammad Arifin, Penunjukan tahkim didasarkan pada kesepakatan dua pihak yang menunjuk hakkam (arbiter) untuk memberikan keputusan hukum guna menyelesaikan persengketaan yang terjadi antara kedua pihak bersengketa berdaarkan petunjuk hukum syarak (Muhammad Arifin, 2016d :10). Legalitas tahkim (arbitrase) diakui dalam al-Quran, hadis, maupun ijmak ulama. Pengakkuan terhadap arbitrase dalam hukum Islam terlihat dalam al-Quran, seperti penyelesaian perselisihan antara suami istri melalui hakam (arbiter) sebagai juru damai (QS. An-Nisa' ayat 35 dan 128).

\section{Prinsipi-prinsip Syariah dalam Perjanjian}

Menurut Metwally seperti dikutip oleh Eko Suprayitno, prinsipprinsip bermuamalah dalam Islam dapat dijabarkan secara garis besar sebagai berikut: (Eko Supriyanto, 2005: 2).

1) Sumber daya alam adalah milik Allah, sehingga pemanfaatannya oleh manusia harus memperhatikan tanggung jawab di akherat. Sehingga dalam pemanfaatannya manusia harus memperhatikan pemanfaatan tidak hanya untuk diri sendiri tetapi juga harus memperhatikan kepentingan orang lain.

2) Hak milik pribadi diakui secara terbatas, ada aspek kepentingan masyarakat yang harus diperhatikan sehingga untuk memperoleh hak pribadi harus mempergunakan cara-cara yang halal atau sah.

3) Islam mengajarkan manusia bekerja dan berjuang untuk mendapatkan harta yang halal dengan cara dan aturan yang telah ditentukan di dalam kitab suci, karena pada dasarnya setiap makhluk telah dijamin rezekinya oleh Allah.

4) Hak kepemilikan kekayaan tidak boleh hanya dikuasai oleh sebagian kecil orang, karena dapat menghambat produktifitas nasional dan memperlambat terciptanya kesejahteraan masyarakat.

5) Sumber-sumber produksi yang penting bagi negara dan yang menguasai hajat hidup orang banyak dijamin penggunaannya untuk kepentingan umum/ orang banyak.

6) Setiap tindakan manusia selalu ada pertanggungjawabannya dihadapa Allah, sehingga mendorong umat Islam untuk menghindarkan diri dari cara-cara yang mengandung unsur riba, maisir, gharar dan upaya yang melampaui batas.

7) Membayar zakat bagi yang telah mencapai nisab adalah bentuk pendistribusian yang adil bagi orang kaya terhadap orang miskin.

8) Riba dalam bentuk apapun dilarang dalam Islam 
Efektifitas Penerapan Prinsip Syariah dalam Penyelesaian Sengketa

Ekonomi Syariah di Badan Arbitrase Syariah Nasional (BASYARNAS)

\section{METODE PENELITIAN}

Pendekatan Suatu penelitian ilmiah dilakukan dalam rangka mencari pemecahan masalah tergantung pada pendekatan yang digunakan (Jhony Ibrahim, 2006: 299). Untuk meneliti efektivitas penerapan prinsip-prinsip syariah dalam penyelesaian sengketa ekonomi syariah melalui Badan arbitrase syariah nasional (Basyarnas) digunakan penelitian hukum normative dengan menggunakan pendekatan konseptual (Peter Mahmud Marzuki, 2008a: 137) dan pendekatan perundang-undangan (Peter Mahmud Marzuki, 2008b: 102). Pendekatan perundang-undangan, adalah pendekatan yang digunakan dalam penelitian dengan menggunakan legislasi dan regulasi (Peter Mahmud Marzuki, 2008c: 97). Sedangkan dalam pendekatan konseptual, yaitu melakukan penelitian terhadap mekanisme penyelesaian sengketa bisnis syariah apakah sudah sesuai dengan prinsipprinsip syariah sebagaimana yang dikehendaki oleh fatwa DSN MUI.

\section{Sifat Penelitian}

Penelitian ini bersifat preskriptif, dalam hal ini memberikan preskripsi bagaimana seharusnya penyelesaian melalui Basyarnas lebih memberikan keadilan dan lebih efektif menerapkan prinsip-prinsip syariah dengan menggunakan teori efektivitas hukum dari Anthony Allot sebagai tolok ukurnya

\section{Jenis dan Sumber Data}

Ada dua data dalam penelitian ini yaitu : pertama, mekanisme penyelesaian sengketa melalui Basyarnas. Kedua, putusan dan dasar pertimbangan arbiter dalam penyelesaian sengekata ekonomi syariah. Kedua jenis data ini merupakan data sekunder publik yang dapat diperoleh dari Basyarnas. Bahan hukum primer yang dibutuhkan dalam penelitian penerapan prinsip syariah ini meliputi : peraturan perundnangundangan yang terkait dengan Basyarnas seperti UU No. 30 Tahun 1999 tentang Arbitrase dan Alternatif Penyelesaian Sengketa, Fatwa MUI tentang Akad-akad syariah. Adapun bahan hukum sekunder dalam penelitian ini meliputi semua publikasi tentang penyelesaian sengketa ekonomi syariah.

\section{Teknik Pengumpulan Data}

Untuk memperoleh data yang dibutuhkan dalam penelitian ini diperlukan teknik pengumpulan data. Adapun teknik pengumpulan data sekunder yang dipergunakan adalah studi pustaka dan content analisys dokumen, arsip, bahan hukum primer dan bahan hukum sekunder. Beberapa data dimintakan penjelasan dan konfirmasi dari Basyarnas dalam penelitian ini peneliti melakukan konfirmasi data di Basyarnas DI.Yogyakarta. 


\section{Analisis Data}

Untuk memperoleh jawaban atas permasalahan penelitian digunakan silogisme deduksi (Soerjono Soekanto dan Sri mamuji, 1990: 88). Untuk menjawab permasalahan pertama, digunakan konsep arbitrase dalam penyelesaian sengketa. Untuk menjawab permasalahan kedua, teori efektivitas hukum dari Anthony Allot ditempatkan sebagai premis mayor, sedang premis minornya penerapan prinsipprinsip syariah dalam penyelesaian sengketa bisnis syariah di Badan Arbitrase Syariah Nasional.

\section{PEMBAHASAN}

\section{Efektivitas Penerapan Prinsip-Prinsip Syariah dalam Penyelesaian Sengketa Ekonomi Syariah}

Pada dasarnya prosedur dan mekanisme penyelesaian sengketa ekonomi syariah di Basyarnas sudah mengikuti ketentuan hukum yang berlaku. Demikian juga penyelesaian sengketa ekonomi syariah di Basyarnas Yogyakarta. Sengketa ekonomi syariah yang masuk ke Basyarnas wilayah Yogyakarta selama tahun 2016 - 2018 ada 17 perkara. Dari ke 17 perkara tersebut sebagian besar perkara diselesaikan secara damai, hanya ada beberapa perkara yang sampai pada pemeriksaan dan akhirnya ada putusan (Dadan Muttaqien, 2018a).

Dasar yang digunakan dalam proses pemeriksaan perkara, di samping menggunakan dasar Al Quran dan Hadis, serta Fatwa DSN MUI, Basyarnas juga menggunakan hukum acara sebagai dasar prosedur penyelesaian perkara. Selain itu UU AAPS juga diterapkan dalam penyelesaian perkara tersebut. Hal ini karena Basyarnas juga merupakan salah satu lembaga arbitrase, hanya saja perkara yang diselesaikan adalah sengketa ekonomi syariah (Dadan Muttaqien, 2018b).

Sengketa ekonomi syariah merupakan sengketa yang timbul dari hubungan hukum dalam bisnis yang kegiatan usahanya didasarkan pada prinsip-prinsip syariah. Sengekta ekonomi syariah timbul disebabkan karena ada salah satu pihak di dalam akad (perjanjian) yang tidak memenuhi isi akad yang sering disebut dengan wanprestasi. Sengketa juga dapat timbul karena perbuatan melawan hukum.

Pada dasarnya penyelesaian sengketa ekonomi syariah baik melalui jalur litigasi maupun non litigasi harus menggunakan prinsip-prinsip syariah dalam penyelesaiannya. Efektif tidaknya suatu perkara diselesaikan oleh suatu lembaga adalah dengan melihat bagaimana preskipsi dari penyelesaian sengketa tersebut.

Mekanisme penyelesaian sengketa ekonomi syariah yang diterapkan di Basyarnas Yogyakarta sudah sesuai dengan UU AAPS dan Hukum Acara Perdata. Dari proses perkara masuk, arbiter selalu berupaya untuk mendamaikan para pihak. Prinsip utama yang dikedepankan oleh 
arbiter dalam menyelesaikan sengketa adalah perdamaian. Para arbiter menggunakan pendekatan dari hati ke hati. Prinsip saling menjaga silaturahmi diantara kedua belah pihak yang dikedepankan. Sengketa yang terjadi antara kedua belah pihak terjadi karena kesalah pahaman dalam menafsirkan isi akad. Sehingga oleh arbiter persengketaan tersebut berusaha untuk di damaikan.

Dalam menyelesaikan sengketa ekonomi syariah dasar utama yang digunakan oleh Basyarnas adalah Alquran, Hadis, Fatwa DSN MUI, Maqashid Syariah dan tidak terlepas dari isi akad itu sendiri. Apabila ada ketentuan akad yang tidak sesuai dengan fatwa DSN MUI sebagaimana seharusnya, barulah Basyarnas akan memberikan jalan penyelesaian agar ketentuan yang mengatur akad yang diperjanjikan untuk diperbaiki. Sehingga tidak merugikan salah satu pihak. Timbulnya sengketa dapat disebabkan karena ada pihak yang tidak memahami dengan baik isi akad, sehingga dengan persepsi yang berbeda tentang ini akad dapat menimbulkan kesalahpahaman.

Dari segi akad atau perjajian yang dibuat oleh para pihak, ada beberapa bentuk akad yang berpotensi sengketa di kemudian hari, diantaranya adalah: (Amran Suadi, 2016d: 33).

a) Salah satu pihak menemukan fakta bahwa syarat-syaratnya suatu akad, baik syarat subjektif maupun objektif yang ternyata tidak terpenuhi sehingga menuntut pembatalan akad;

b) Akad diputus oleh satu pihak tanpa persetujuan pihak lain dan perbedaan menafsiran isi akad oleh para pihak sehingga menimbulkan sengekta hukum;

c) Karena salah satu pihak tidak memenuhi prestasi sebagaimana yang telah diperjanjikan;

d) Terjadinya perbuatan melawan hukum

e) Adanya risiko yang tidak terduga pada saat pembuatan akad.

Dalam perkara tersebut di atas, timbulnya sengketa disebabkan karena salah satu pihak tidak memenuhi prestasi sebagaimana yang telah diperjanjikan. Akan tetapi apabila Basyarnas memeriksa penyebab timbulnya wanprestasi karena kesalahan salah satu pihak, maka penyelesaiannya diupayakan secara damai, dan tidak sampai pada eksekusi benda jaminan. Dan pihak yang bersalah harus membayar ganti kerugian kepada pihak yang dirugikan. Penyelesaian yang dilakukan Basyarnas tersebut sudah sesuai dengan prinsip-prinsip syariah.

Langkah-langkah yang dilakukan oleh Basyarnas yang demikian dapat dikatakan sudah efektif. Karena apa yang dikehendaki oleh hukum (dalam hal ini) penyelesaian sengketa ekonomi syariah harus menggunakan juga prinsip-prinsip syariah. Dengan demikian tujuan yang ingin dicapai dalam sengketa tersebut dapat terwujud. Karena akad yang 
telah disepakati adalah akad syariah, maka penyelesaiannya juga harus menggunakan prinsip syariah.

Dasar pertimbangan hukum Basyarnas dalam memeriksa dan memutus perkara No. 02/2017/ / Basyarnas/Put/Ka.DIY dapat diuraikan sebagai berikut.

Putusan Basyarnas sebagaimana dimaksud adalah untuk memutus sengketa akad musyarakah antara Pemohon A dengan Termohon B dan C. Dalam persengketaan tersebut Termohon telah melakukan wanprestasi dengan tidak melakukan pembayaran dari piutang pokok dan bagi hasil sebesar 27.223.000 sesuai dengan jangka waktu yang telah disepakati. Atas tuntutan pembayaran kewajiban tersebut termohon tidak melakukan pembayaran, sehingga oleh pemohon perbuatan termohon tersebut telah merugikan kepentingan termohon.

Dalam tuntutannya, pemohon menuntut termohon untuk membayar tunggakan pokok sebesar 27.233.000, bagi hasil sebesar 10.430 .000 dan biaya penyelesaian permasalahan hukum sebesar 10.000.000. Di dalam putusan tersebut tidak disebutkan berapa pembayaran yang telah dilakukan oleh Termohon B dan C. Di dalam putusan tersebut tidak ada keterangan mengenai pembayaran yang telah dilakukan oleh Termohon B dan $C$ dari kewajiban setiap bulannya sebesar 2.158.333. Sehingga dapat dihitung berapa sisa pembayaran yang seharusnya menjadi kewajiban Termohon B dan C. Basyarnas juga dapat memperhitungkan berapa jumlah piutang atau kerugian yang seharusnya dibayarkan kepada Pemohon A.

Di dalam permohonan tersebut tidak dijelaskan berapa pokok pinjaman yang sudah diangsur dari total pinjaman sebesar 35.000.000, demikian juga bagi hasil yang dituntut sebesar 10.430.000 dengan perhitungan yang tidak jelas. Bila melihat waktu terjadinya akad, maka seharusnya akad tersebut sudah lunas pada bulan Februari 2012. Sementara Termohon telah melakukan pembayaran terakhir pada Desember 2013. Hal ini yang membuat tidak lengkapnya keterangan dalam putusan Basyarnas.

Pada dasarnya prinsip yang terkadung di dalam akad musyarakah dimanapun sama. Sesuai dengan Fatwa DSN MUI tentang musyarakah bahwa perhitungan bagi hasil setiap bulannya tidak dapat ditentukan jumlah nominalnya. Yang dapat ditentukan nisbah bagi hasil adalah prosentase keuntungan antara nasabah dengan Shahibul mal, misal 60 : 40 persen. Dalam akad Musyarakah yang terjadi antara nasabah dengan BMT telah disepakati jumlah angsuran tiap bulannya yang dihitung dari jumlah pembelian sebesar 35.000.000 dan margin keuntungan sebesar 16.800.000, padahal akad tersebut bukan murabahah.

Adanya kesalahan dalam akad seharusnya diluruskan oleh Basyarnas dengan menggunakan prinsip musyarakah. Artinya secara 
preskriptif bahwa di dalam akad musyarakah tidak dikenal margin keuntungan, yang ada adalah nisbah bagi hasil sebagaimana diatur di dalam fatwa DSN-MUI No: 08/DSNMUI/IV/2000 Tentang Pembiayaan Musyarakah. Akan tetapi dalam hal penyelesaian sengketa akad musyarakah dalam Putusan No. 02/Th.2017/Put/BASYARNAS/DIY terdapat kesalahan dalam akad, hal ini tidak ada upaya yang dilakukan oleh Basyarnas untuk memperbaiki akad. Sengketa akad musyarakah antara pemohon dan termohon, dalam putusan tersebut, pemohon menuntut margin keuntungan. Seyogyanya Basyarnas tidak mengabulkan margin keuntungan yang dituntut oleh pemohon. Karena dalam akad musyarakah tidak dikenal margin keuntungan, yang ada adalah bagi hasil. Apabila usaha yang dijalankan tidak berjalan maka bagi hasil juga tidak dapat dituntut. Yang dapat dituntut untuk dikembalikan oleh nasabah adalah pokok pinjaman. Dengan demikian dalam penerapan prinsip syariah belum dilakukan, sehingga menurut Anthony Allot penerapan prinsip syariah belum efektif.

Tidak ada upaya untuk meluruskan akad yang terjadi antara pemohon dengan termohon, sebagaimana dalam Fatwa MUI tentang akad Musyarakah menunjukkan bahwa prinsip syariah dapat dikatakan gagal mencapai tujuanya, karena dalam akad musyarakah tidak dikenal margin keuntungan. Dan apabila usaha yang dijalankan berhenti beroperasi maka kedua belah pihak tidak akan mendapatkan nisbah bagi hasil. Karena tidak berjalannya usaha syirkah antara keduanya maka nisbah bagi hasil juga tidak dapat dituntut oleh pihak bank.

Menurut toeri Antony Allot, hukum dalam hal ini prinsip-prinsip syariah menjadi efektif jika di dalam menyelesaikan sengketa ekonomi syariah, apabila Basyarnas menerapkan prinsip-prinsip syariah atau fatwa DSN MUI untuk menyelesaikan sengketa yang ditangani. Sehingga kebenaran yang diutamakan adalah kebenaran materil sesuai dengan prinsip-prinsip syariah. Meskipun sudah ada akad yang disetujui oleh para pihak, Basyarnas juga harus meneliti apakah ada kesalahan dalam isi akad. Karena pada umumnya terjadinya sengketa juga disebabkan karena salah satu pihak dalam hal ini biasanya nasabah yang tidak mengetahui betul isi akad.

Efektif dan tidaknya prinsip-prinsip syariah dalam putusan tersebut dapat dilihat dari dasar pertimbangannya. Dalam pertimbangannya Basyarnas telah menggunakan Alquran sebagai dasar putusannya, akan tetapi prinsip syariah sebagaimana yang terkandung di dalam fatwa MUI Tentang Pembiayaan Musyarakah pada poin tuntutan margin keuntungan belum sesuai. Karena akad musyarakah tidak di kenal margin keuntungan. Hal ini tidak sejalan dengan Fatwa MUI tentang akad Musyarakah yaitu : (MUI, 2018). 
1) Pembagian keuntungan didasarkan pada porsi kerja secara proporsional.

2) Kedudukan para pihak harus dijelaskan dalam kontrak, sehingga pembagian keuntungan antara pihak yang satu dengan yang lain sesuai dengan kedudukan di dalam organisasi.

3) Pembagian keuntungan harus ditentukan secara jelas proporsinya antara pihak yang satu dengan yang lain di dalam kontrak sehingga tidak menimbulkan perselisihan dan kesalahpahaman.

4) Ditentukan dengan jumlah tertentu pada saat awal akad yang ditetapkan oleh salah seorang pihak.

5) Apabila terjadi kerugian, maka pembagian kerugian juga dilakukan secara proporsional.

Demikian halnya tentang kerugian, kerugian harus dibagi di antara para mitra secara proporsional menurut saham masing-masing dalam modal. Oleh karena itu maka bagi hasil yang dituntut oleh pemohon tidak dikabulkan oleh Basyarnas, hal ini karena usaha yang dijalankan oleh Termohon B dan $\mathrm{C}$ tidak berjalan sehingga sudah tidak menghasilkan keuntungan lagi.

Karena usaha yang dijalankan oleh Termohon tidak berjalan menyebabkan keuntungan usaha tidak ada maka Termohon tetap mempunyai kewajiban untuk mengembalikan sisa pinjaman pokok setelah dipotong angsuran yang telah dibayarkan. Akan tetapi di dalam putusan tersebut tidak dijelaskan berapa angsuran yang telah dibayarkan oleh Termohon. Pemohon hanya meminta tuntutan sisa utang sebesar 27.233.000 tanpa memberikan rincian dari sisa angsuran yang telah dibayarkan oleh Termohon.

\section{KESIMPULAN}

Dari pembahasan di atas, dapat disimpulkan beberapa hal sebagai berikut: pertama, prinsip-prinsip syariah belum maksimal diterapkan oleh Basyarnas, hal ini dapat dilihat dari dasar pertimbangan hukum Basyarnas dalam putusannya. Seharusnya Basyarnas mengoreksi isi akad, apakah sudah sesuai dengan prinsip syariah atau tidak sehingga timbulnya sengketa bukan semata-mata disebabkan oleh wanprestasinya nasabah akan tetapi dapat juga disebabkan karena tidak sesuainya akad dengan prinsip-prinsip syariah.

Menurut teori efektivitas Antony Allot bahwa penerapan prinsipprinsip syariah dalam penyelesaian sengketa ekonomi syariah di Basyarnas belum sepenuhnya efektif, hal ini disebabkan karena masih ada beberapa hal yang belum diterapkan oleh Baysarnas, khususnya mengenai tinjauan isi akad dalam pemeriksaan perkara No. 02/Th.2017/BASYARNAS/Put./Ka..DIY. Meskipun akad-akad syariah telah disepakati kedua belah pihak, apabila terdapat kekeliruan, maka 
Efektifitas Penerapan Prinsip Syariah dalam Penyelesaian Sengketa Ekonomi Syariah di Badan Arbitrase Syariah Nasional (BASYARNAS)

Basyarnas dapat memberikan opini hukum terhadap akad yang tidak sesuai fatwa DSN MUI. Sehingga tujuan yang dikehendaki adanya penerapan prinsip-prinsip syariah dalam penyelesaian sengketa ekonomi syariah dapat terwujud.

\section{DAFTAR PUSTAKA}

Arifin, Muhammad, Arbitrase Syariah sebagai Pilihan Forum Penyelesaian Sengketa Perbankan Syariah, Yogyakarta: Pustaka Pelajar, 2016.

Badan Arbitrase Syariah Nasional, Profil dan Prosedur, Jakarta, 2003

Defta Zona, Rika, Penyelesaian Sengketa Perbankan Syariah di Indonesia, dalam jurnal Economic: Jurnal Ekonomi dan Hukum Islam, Vol. 4, No . 1, 2014.

Ibrahim, Johnny, Teori dan Metodologi Penelitian Hukum Normatif, Malang: Bayumedia Publising, 2006.

La Hafi, Fikri, Budiman, Penerapan Asas Lex Specialis Derogat Legi Generalis dan Penyelesaian Sengketa Ekonomi dalam UndangUndang Perbankan Syariah di Indonesia, dalam jurnal Al-Ihkam: Jurnal Hukum dan Pranata Sosial, Vol 12, No , IAIN Madura, 2017.

Mahmud Marzuki, Peter, Penelitian Hukum, Jakarta: Kencana prenada Media group, 2008.

Nurhasanah dkk, Kecenderungan Masyarakat Memilih Lembaga Penyelesaian Sengketa Ekonomi Syariah, Ahkam Vo. XVI, No, 2 Juli 2016.

Muttaqien, Dadan, Wawancara Pribadi, tanggal 16 Agustus 2018

Shomad, Abd, Hukum Islam, Penormaan Prinsip Syariah dalam Hukum Indonesia, Jakarta: Kencana Prenada Media group, 2010.

Soekanto, Soerjono dan Sri Mamuji, Penelitian Hukum Normatif, Suatu Tinjauan Singkat, Jakarta: Rajawali Press, 1990.

Suadi, Amran, Penyelesaian Sengekta Ekonomi Syariah, Jakarta: Prenada Media Group, 2018.

Subekti, Arbitrase Perdagangan, Bandung: Bina Cipta, 1992.

Sulistiyono, Adi, Mengembangkan Paradigma Non-Litigasu di Indonesia, Surakarta: Sebelas Maret University Press, 2006.

Eko Suprayitno, Ekonomi Islam Pendekatan Ekonomi Makro Islam dan Ekonomi Konvensional, Yogyakarta, Graha Ilmu, 2005.

http:/ / business-law.binus.ac.id/2015/02/17/ penyelesaian-sengketa-pe rbankan-syariah-di-indonesia-bagian-1-dari-2-tulisan/diakses tanggal 27 April 2017

https://tafsirq.com/fatwa/dsn-mui/pembiayaan-musyarakah, diakses tanggal 29 Juli 2018 
Zaidah Nur Rosidah dan Layyin Mahfiana

Halaman ini sengaja dikosongkan 